\author{
Dmytro Voronets \\ PhD student \\ Scientific adviser: Garafonova O., Doctor of Economics, Professor, Professor of Management Department, Economics and Management \\ Faculty, \\ Kyiv National Economic University, Kyiv, Ukraine \\ E-mail: dmitry.ovm@gmail.com \\ ORCID ID: 0000-0002-1972-8574
}

\title{
Efficiency evaluation of the diversification of the enterprise activity in the temporary accommodation and catering field
}

\begin{abstract}
The temporary accommodation and catering field is a highly competitive field that is why companies in this branch of economy have to make strategic decisions concerned with market expansion and diversification. Diversification of the enterprise activity is very complex and comprehensive strategic decision and has to be evaluated and supervised by management of the enterprise. Besides, the implementation of the diversification strategy requires a lot of resources (financial, material, human) which efficiency is important to evaluate and control. In this article it is examined the problem of evaluating the diversification efficiency of temporary accommodation and catering businesses. The essence of diversification of the enterprise activity is revealed and the general characteristic of the field of temporary accommodation and catering is outlined. The author's goal was to specify indicators for evaluating the efficiency of diversification that are developed in latest scientific publications for use in manufacturing enterprises and their adaptation to the services sector, part of which is the temporary accommodation and catering field. On the basis of the researched scientific works the universal system of indicators for estimation of efficiency of diversification of the temporary accommodation and catering enterprise activity is offered. Three key groups of indicators for evaluation are distinguished: financial and economic, manufacturing and technological, market. Formulas for calculating these indicators are given and their nature is described. The aim of this indicators is to demonstrate the quantitative effect of diversification of the enterprise activity in temporary accommodation and catering field. Besides, indicators also can be adapted and used in other service industries.
\end{abstract}

\author{
Keywords \\ diversification efficiency \\ indicators, temporary \\ placement and catering \\ industry, hotel market, \\ restaurant market
}

JEL: M11

\section{Latest scientific progress and publications review}

Diversification is one of the central topics of researches in strategic management. Diversification strategy is one of the four growth strategies identified by Igor Ansoff in 1957 [1]. According to Rumelt, diversification is defined as firm expansion to make/sell products that have no market interaction with the firm's other products [2]. Since Rumelt [3] first tied diversification strategy to financial performance and investigated the correlation between diversification strategy and companies performance, the effects of diversification on the performance of firms have been intensively investigated. In publications [47] researchers also explores correlation between the level of diversification and organizational performance, but they do not consider quantitative indicators and indices of diversification efficiency.

The process of evaluation of diversification efficiency is a component of a strategic planning system at the enterprises. The effectiveness of the nature of strategic planning in firms, as opposed solely to performance outcomes has been 
highlighted as a major problem, according to Dyson, Foster [8] and Greenley [9]. Kotler [10] and Foster [11] have proposed methods to evaluate the strategic planning system (SPS). There have been two main approaches to evaluate the effectiveness of a strategic planning system - process and endsoriented, according to Foster [11]. The process approach considers the whole system and provides users with a means of identifying weaknesses, while end-oriented focuses on the outputs of the system. While Foster [11] recommends the sole use of the first approach, Phillips and Moutinho [12-14] have shown that perhaps the best measure of effectiveness is to include a combination of both approaches. In these publications, the authors focus on the effectiveness of the strategic management system as a whole, with no specifics for assessing the efficiency of enterprise diversification strategies.

Today in scientific literature there is no unified system for evaluating the efficiency of enterprises ' diversification. Researches [15-21] suggest different approaches and different indicators to evaluate the efficiency and diagnosis of diversification at an enterprise. It should be noted that in the process of scientific research, no works that describe approaches to assessing the efficiency of diversification of the activities of enterprises in the service industries, including the temporary accommodation and catering businesses were found. Despite this, there is a need for the management of a companies that implements a diversification strategy of its activities to evaluate the efficiency of diversification processes and investments in diversification.

\section{The purpose and problem of research}

The purpose of the article is to make a system of indicators that help to evaluate the efficiency of the diversification of the enterprise activity in the temporary accommodation and catering field. Additional goals of the article are:

1) to define the necessity of efficiency evaluation of the diversification of the enterprise activity in the temporary accommodation and catering field;

2) to determine responsible department and mangers, who should implement this evaluation;

3) to identify main group of indicators, that should be calculated to in order to get a comprehensive estimation of evaluate the efficiency of the diversification of the enterprise activity in the temporary accommodation and catering field;

4) give a description of each indicator and a calculation formula.

\section{Results of the research}

Area of temporary accommodation and catering brings together a number of markets, the main of which are the restaurant business and hotel business. Businesses operating in these markets today, face such problems as high competition, economic and political crisis in Ukraine, the dynamic of the emerging market trends that need to constantly update the list of services and opportunities for clients, in order to attract visitors, to form a permanent base and increase customer loyalty. Therefore, in modern conditions of doing business, executives often have to make strategic decisions about implementation of the diversification strategy at the enterprise. In connection with this there is a need to evaluate the diversification efficiency of activity of the enterprise, and therefore to the managers who are engaged in management of such project it is important to have a system of indicators for assessing economic and social effect of diversification processes at the enterprise.

The development of the project, its implementation and evaluation of its efficiency occurs within the economic management of the enterprise. In this regard, it is natural to assess the efficiency of the diversification of the enterprise, and therefore managers who manage such a project, as well as the economic service of the enterprise, it is important to have a system of indicators to assess the economic impact of diversification processes at the enterprise.

Diversification strategy can be defined as "expanding or entering in new markets which are different from the firm's existing product lines (services) or markets". Another definition of diversification strategy is "a strategy implemented by the top executives in order to achieve business growth by entering new businesses and attaining above-average returns by taking advantage of the incoming opportunities" [7, p. 1496].

Diversification is a rapid growth strategy. There are four different strategies according to the strategic diversification model developed by Igor Ansoff [1, 22, 23] and applied to the restaurant business by Marcel Coté [24] (Table 1). The approaches are the following:

1) Market Penetration strategy - the least risky "stay the same": exploit the same market with the same restaurant, make it bigger;

2) Market Development strategy: conquer a new market with the same type of restaurant;

3) Product Development strategy: open a different type of restaurant in the same market;

4) Pure Diversification strategy - the highest risk: open a different type of restaurant in a 
TABLE 1 Strategic Diversification Model*

\begin{tabular}{|c|c|c|}
\hline \multirow{3}{*}{ New market } & Same product & New product \\
\hline & Market development & Pure diversification \\
\hline & Offer same service in a new market (e.g. franchise) & Offer a new service in a new market \\
\hline \multirow{2}{*}{ Same market } & Market Penetration & Product development \\
\hline & Develop your market further with your current service & Open a new service in the same market \\
\hline
\end{tabular}

*According to Igor Ansoff [1], as applied by Marcel Côté [24]

new market.

According to Harrison and Enz [25, p.164], there are a number of strategic reasons or opportunities to diversify:

- reduce risk by investing in different businesses or less competitive sectors;

- stabilize and grow revenues;

- improve overall growth of one's activities;

- use cash surplus;

- exploit under- or unused resources, capacity, and competencies;

- create synergies;

- reduce inter-business costs;

- use borrowing capacity (leverage);

- integrate and exploit new technologies;

- increase one's power on the market.

Besides, according to Harrison and Enz, owners or general managers could want to diversify their restaurant's activities for the following reasons:

- enhance the value of the business;

- extend their operations and responsibilities across a larger set of resources (e.g., employees, buildings, networks);

- increase their salary and bonus;

- create a work environment with a more refined management style and more specialized positions.

Once the decision is made to diversify and in which direction, the restaurant management team won't throw itself in too many new projects at the time. All these decisions are part of a strategic plan, with attainable goals for which the team is accountable for. It's important not to lose sight of the restaurant's missions and global objectives.

The implementation of the diversification strategy is aimed at getting a certain economic effect, so the management of the enterprise is interested in obtaining estimated rates to control the implementation process of this strategy.

It should be emphasized that evaluating the efficiency of a diversification strategy is an indisputable object of economic management of an enterprise, in accordance with the generally recognized objects of economic governance, which are:

1) results of economic activity;

2) economic resources required for such activities (economic potential of the enterprise);

3) the integral characteristics of the state in which the enterprise is located due to economic activity and the existing level of use of available resources (realization of economic potential) [15, p. 109]. That is on the basis of analytical information of the subsystem of economic management of the enterprise that analysis, diagnostics and evaluation of indicators of efficiency of a diversification strategy can be carried out.

Temporary accommodation and catering enterprises in Ukraine are presented in the form of small, medium and large enterprises, as well as in the form of individual entrepreneurs. Depending on the size of the enterprise and the appropriate organizational structure that diversifies its activity, entities of economic management of the enterprise could be:

1) persons of economic service of the enterprise itself;

2) specialists in economic management of diversification project of the enterprise's activity;

3) or economic management functions, including the evaluation of diversification efficiency, should be entrusted to the management of the enterprise of the diversification project concerned.

It should be emphasized that in the process of evaluating the efficiency of enterprise diversification it is important to take into account, first of all, such principles of economic management as systemic and complexity [15, p.116]. That is, to get a holistic picture of the efficiency of enterprise diversification, it is necessary to thoroughly analyse all subsystems of the company that have been affected by the project of diversification of activity, namely: financial, economic, industrial, technological, information, and in addition it is necessary to take into account the impact on the external environment of the enterprise, especially markets in which it operates and consumer loyalty.

The efficiency of a diversification strategy can be defined as ratio of spent investments (resources) and the obtained result (effect).

On the basis of scientific research analysis [1621 ], it is proposed a system of indicators for evaluating diversification of enterprises in the field of temporary accommodation and catering. For convenience indicators can be grouped as follows (Figure 1). 

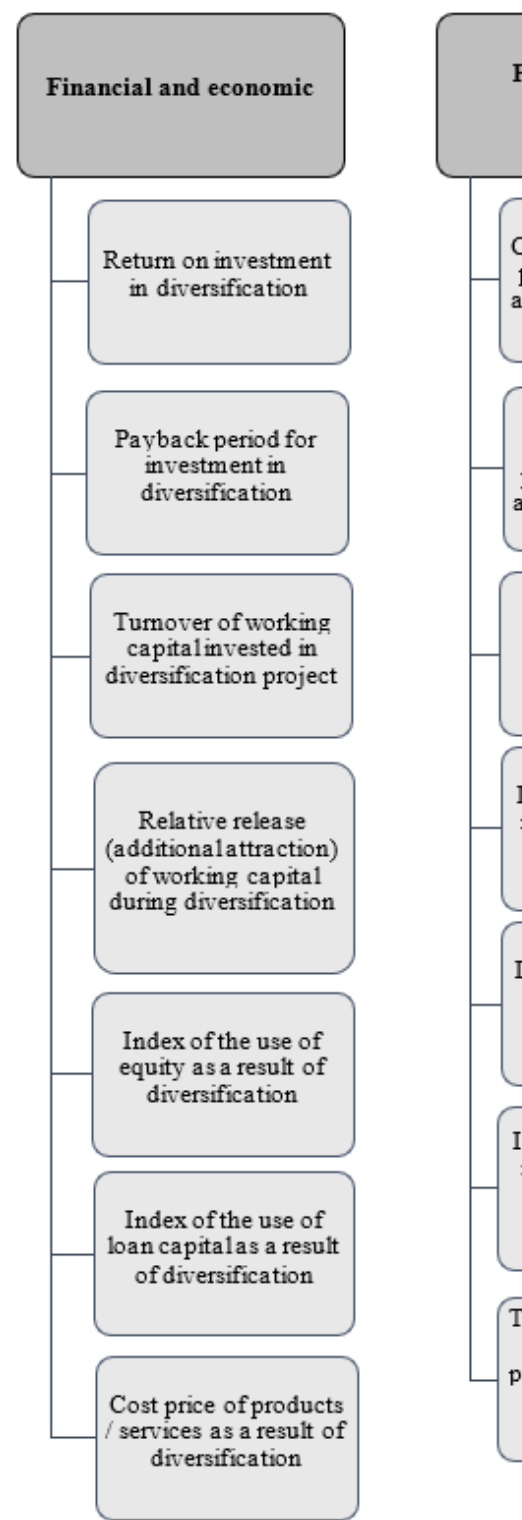

Capital productivity of products/ services of a diversified enterprise

roduction and technological

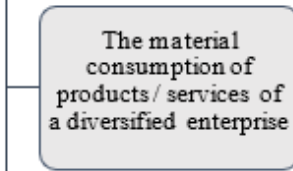

Labor productivity index as a result of diversification

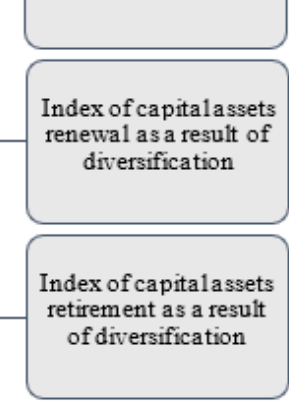

Index of a technology implementation as a result of diversification

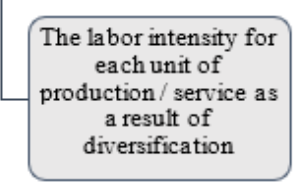

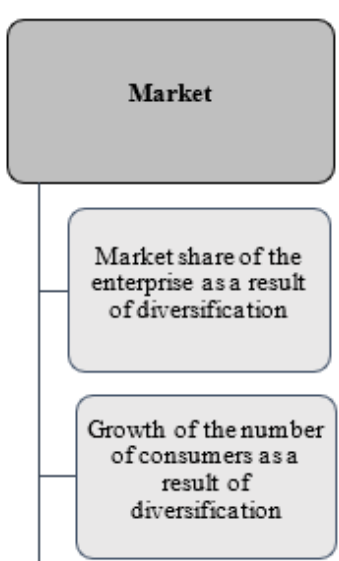

Index of consumer satisfaction as a result of diversification

Index of satisfaction of market needs for products/services of diversified production

Figure $1 \mathrm{~A}$ system of indicators for evaluating the efficiency of enterprise diversification (Developed by author based on [3-8])

Return on investment in diversification $R_{D}$. If the diversification strategy is implemented as an independent project that is clearly defined the amount of investment, and we can separate the income that came from the implementation of this project, the efficiency of diversification $R_{D}$ is possible to define as the ratio of the profit $P_{D}$ to the investment $I_{D}$ :

$$
R_{D}=\frac{P_{D}}{I_{D}}
$$

$R_{D}$ - return on investment in diversification; $P_{D}$ profit from sales of products / services as a result of diversification; $I_{D}$ - the amount of investment in the diversification project.

The higher the value of this indicator, the more effective the diversification strategy of the

\section{enterprise.}

Payback period for investment in diversification $D P P_{D}$. This is an indicator that defines the time it takes to return the investment in the diversification project:

$$
D P P_{D}=\sum_{t=1}^{n} \frac{C F_{t}}{(1+r)^{t}} \geq I_{0}
$$

$D P P_{D}$ - discounted payback period of investment in diversification; $C F_{t}$ - cash flow (income) from products / services as a result of diversification; $n$ number of years of project duration; $r$ - is the discount rate; $I_{0}$ - the value of investment in the project.

Turnover of working capital invested in diversification project $C_{D}$. This is an indicator that determines the number of turnovers that invested working capital made during a certain period: 


$$
C_{D}=\frac{E_{D}}{C_{C}}
$$

$C_{D}$ - number of turnovers; $E_{D}$ - income from sales of products / services, as a result of diversification; $C_{C}$ - working capital invested in the diversification project.

Relative release (additional attraction) of working capital during diversification $S_{D}$. Determines the amount of release (or additional attraction) of funds as a result of their acceleration (deceleration):

$$
S_{D}=\left(T_{C}^{1}-T_{C}^{0}\right) \times \frac{E_{D}}{n}
$$

$S_{D}$ - relative release (additional attraction) of working capital during diversification; $T_{C}^{1}$ - the actual duration of the capital turnover as a result of diversification; $T_{C}^{0}$ - basic duration of capital turnover; $E_{D}$ - revenue from sales of products / services as a result of diversification; $n$ - number of days in the period for which the working capital turnover is calculated.

Index of the use of equity as a result of diversification $I P C_{D}$. This indicator determines the degree of equity that is used for realization of diversification project of enterprise activity:

$$
I P C_{D}=\frac{P C_{D}}{P C}
$$

$I P C_{D}$ - index of the use of equity as a result of diversification; $P C_{D}$ - equity involved in the diversification process; $P C$ - total equity.

Index of the use of loan capital as a result of diversification $I B C_{D}$. This index determines the correlation of loaned capital used in diversification project and the total amount of loaned capital:

$$
I B C_{D}=\frac{B C_{D}}{B C}
$$

$I B C_{D}$ - index of use of loan capital as a result of diversification; $B C_{D}$ - loan capital involved in the diversification process; $B C$ - total loan capital.

Cost price of products / services as a result of diversification $P C_{D}$. This is an indicator that determines the amount of cost to produce the product or create and provide services that were implemented as a result of diversification:

$$
P C_{D}=\frac{F C_{D}}{V_{D}}+V C_{D}
$$

$P C_{D}$ - cost price of products / services as a result of diversification; $F C_{D}$ - fixed cost of producing products / creating and providing services as a result of diversification; $V_{D}$ - volume of production / providing services as a result of diversification; $V_{D}$ - variable costs of production / creation and providing services as a result of diversification.

\section{Production and technological}

Capital productivity of products / services of a diversified enterprise $F_{D}$. This is an indicator that determines the revenue from the sales of products of diversified production that accounts for one unit of key productive assets:

$$
F_{D}=\frac{E_{D}}{P F_{D}}
$$

$F_{D}$ - capital productivity of products / services of a diversified enterprise; $E_{D}$ - income from sales of products / services as a result of diversification; $P F_{D}$ - key productive assets of the enterprise.

The material consumption of products / services of a diversified enterprise $M_{D}$. This is an indicator that determines how much material costs accounted for each currency unit of products / services that were made as a result of a diversification:

$$
M_{D}=\frac{M C_{D}}{S_{D}}
$$

$M_{D}$ - material consumption of products / services of a diversified enterprise; $M C_{D}$ - the amount of material costs for production / creation and providing services of a diversified enterprise; $S_{D}$ cost of products / services of diversified enterprise.

Labour productivity index as a result of diversification $I P L_{D}$. This is an indicator that determines the correlation between the labour productivity index after diversification of activity and productivity of the enterprise which had been in the enterprise before the implementation of the diversification project:

$$
I P L_{D}=\frac{P L_{D}}{P L_{0}}
$$

$I P L_{D}$ - labour productivity index as a result of diversification; $P L_{D}$ - labour productivity as a result of diversification; $P L_{0}$ - labour productivity before the implementation of the diversification project.

Index of capital assets renewal as a result of diversification $I N A_{D}$. This is an indicator that determines the degree of capital assets renewal due to the implementation of diversification at the enterprise:

$$
I N A_{D}=\frac{N A_{D}}{A}
$$

$I N A_{D}$ - index of capital assets renewal as a result of diversification; $N A_{D}$ - cost of commissioning of the capital assets during the diversification project; $\mathrm{A}$ - the total value of capital assets of the enterprise. Index of capital assets retirement as a result of diversification $I R A_{D}$. This is an indicator that determines the degree of capital assets retirement due to the implementation of diversification at the enterprise: 


$$
I R A_{D}=\frac{R A_{D}}{A}
$$

$I R A_{D}$ - index of capital assets retirement; $R A_{D}$ capital assets retirement as a result of diversification; $A$ the total value of capital assets of the enterprise.

Index of a technology implementation as a result of diversification $I T_{D}$. This is an indicator that determines the degree of new technologies implementation as a result of diversification:

$$
I T_{D}=\frac{T_{D}}{T}
$$

$I T_{D}$ - index of a technology implementation as a result of diversification; $T_{D}$ - the amount of technologies implemented as a result of diversification; $T$ - total amount of technologies at the enterprise.

The labour intensity for each unit of production / service as a result of diversification. This is an indicator that determined time spent on manufacturing a unit of production of diversified enterprise, efficiency of implementation of science and technology, mechanization, automation, improvement of production and labour organization:

$$
L P_{D}=\frac{t_{d}}{Q_{d}}
$$

$L P_{D}$ - the labour intensity for each unit of production / service as a result of diversification; $t_{d}$ - the working time to produce products / provide services in the result of diversification; $Q_{d}$ - volume of production.

\section{Market}

Market share of the enterprise as a result of diversification $M S_{D}$. This is an indicator that determines the market share a business occupies as a result of implementation of diversification:

$$
M S_{D}=\frac{E_{D}}{E E}
$$

$M S_{D}$ - market share of the enterprise as a result of diversification; $E_{D}$ - income from sales of diversified products / services; EE - total sales of products / services in the market.

Growth of the number of consumers as a result of diversification $I C I_{D}$. This is an indicator that determines the increase in the number of consumers as a result of diversification activity of the enterprise:

$$
I C I_{D}=\frac{C I_{D}}{C}
$$

$I C I_{D}$-growth of the number of consumers as a result of diversification; $C I_{D}$ - the number of new consumers involved as a result of diversification;
$C$ - the total number of consumers of a particular product / service of the enterprise in the given market.

Index of consumer satisfaction as a result of diversification $I C S_{D}$. This is an indicator that determines the degree of customer satisfaction of products / services produced as a result of diversification of enterprise activity, within the market of the given product / service:

$$
I C S_{D}=\frac{C S_{D}}{C}
$$

$I C S_{D}$ - index of consumer satisfaction as a result of diversification; $C S_{D}$ - number satisfied consumers as a result of diversification; $C$ - the total number of consumers of a particular product / service of the enterprise in the given market.

Index of satisfaction of market needs for products / services of diversified production $I M S_{D}$. This is the indicator that determines the market saturation of products / services produced as a result of enterprise activity diversification.

$$
I M S_{D}=\frac{Q_{D}}{D_{D}}
$$

$I M S_{D}$ - index of satisfaction of market needs for products / services of diversified production; $Q_{D}$ - sales of the diversified enterprise; $D_{D}$ - demand forecast for a given product / service in the market.

This system of indicators allows to evaluate fully the efficiency of diversification strategy implementation at the enterprise. The use of indicators is possible not only for temporary enterprises of accommodation and catering, but also for businesses in other areas of economic activity.

\section{Conclusion}

Diversification strategy as a growth strategy is used today in the temporary accommodation and catering field as well as in manufacturing fields, and in service fields of economy. Evaluation of the efficiency of diversification of enterprise activity can be realized only if a responsible manager or service of the enterprise has a specific system of indicators. It is an important aspect in managing project of diversification activity of the enterprise. The presence of a single formalized system indicators can facilitate the process of analysing the efficiency of project of the implementation of diversification of activity at the enterprise. In addition, this system of indicators should be taken into account in the economic service of the enterprise and used within the system of economic management.

The main groups of indicators are: financial and economic, production and technological, market. Together, all of the above indicators provide a comprehensive assessment of efficiency of the diversification of the enterprise activity in the temporary accommodation and catering field. 


\section{References}

[1] Ansoff I 1957 A Model for Diversification Burbank, Lockheed Aircraft Corporation

[2] Rumelt R P 1982 Diversification strategy and profitability Strategic Management Journal 3 359-69

[3] Rumelt R P 1974 Strategy, Structure and Economic Performance Boston, MA: Harvard Business School Press $134 \mathrm{p}$

[4] Ginevicius R, Podvezko V, Andruskevicius A 2008 The Effectiveness of Diversification of Construction Enterprise Activities Proceedings of the 25 $5^{\text {th }}$ ISARC, Vilnius, Lituania 759-63

[5] Li C M, Cui T, Nie R, Lin H, Shan Yu 2019 Does diversification help improve the performance of coal companies? Evidence from China's listed coal companies Elsevier 61(C) 88-98

[6] Manchun H, Sanghyo L, Jaejun K 2019 Effectiveness of Diversification Strategies for Ensuring Financial Sustainability of Construction Companies in the Republic of Korea Sustainability 11(11) 3076

[7] Anıla I, Yiğitb I 2011 The Relation between Diversification Strategy and Organizational Performance: A Research on Companies Registered to the Istanbul Stock Exchange Market Elsevier, Procedia-Social and Behavioral Sciences 24 1494-509

[8] Dyson R G, Foster M J 1980 Effectiveness in strategic planning European Journal of Operational Research 5(3) 163-70

[9] Greenley G E 1983 Effectiveness in marketing planning Strategic Management Journal 4(1) 1-10

[10] Kotler P 1997 From sales obsession to marketing effectiveness Harvard Business Review 55(6) 67-75

[11] Foster M J 1994 Calibrated scales for diagnosing planning effectiveness Asia Pacific Journal of Operational Research 11(2) 171-85

[12] Phillips P A, Moutinho L 1998 Strategic Planning Systems in Hospitality and Tourism CAB International, Oxford

[13] Phillips P A, Moutinho L 1998 The marketing planning index (MPI): it's use and application in the hospitality sector Journal of Hospitality and Leisure Marketing 5(2) 5-26

[14] Phillips P A, Moutinho L 1999 Measuring strategic planning effectiveness in hotels International Journal of Contemporary Hospitality Management 11(7) 349-58

[15] Lihonenko L O, Vysochyn I V, Piratovskyi H L 2013 Research Report on "Economic Management of Enterprise" Kyiv 879 p (in Ukainian)

[16] Skrynkovskyi R M, Vizniak Yu Ya, Pavlovski H, Koropetskyi O O 2017 Diagnosis of diversification processes at the enterprise Problems of economy 2 223-8 (in Ukainian)

[17] Drymalovska Kh V 2016 Development of diversification at the enterprise Diss. cand. econom. of sciences: 08.00.04. Lviv Polytechnic National University, Lviv, 219 p (in Ukainian)

[18] Strelchuk Y M, Kaluhina N A 2014 Efficiency of diversification of activity of the telecommunication enterprise Economy: The Realities of Time Scientific journal 2(12) 28-33 (in Ukainian)

[19] Korinko M D 2008 Control and analysis of activity of economic entities in the conditions of its diversification: theory, methodology, organization Kyiv 38 p (in Ukainian)

[20] Tsohla O O 2008 Evaluation of efficiency of diversification of activity of machine-building enterprise Journal of Lviv Polytechnic National University. Series of Economics and Management Issues 628 337-47 (in Ukainian)

[21] Zakharin S V 2012 Economic diversification as an effective mechanism for ensuring enterprise development Visnyk KNUTD 1 138-45 (in Ukainian)

[22] Ansoff H I 1965 Corporate Strategy New York, NY: McGraw-Hill 241 p

[23] Ansoff H I 1990 Implanting Strategic Management Englewood, NJ: Prentice-Hall; 2 edition, 500 p

[24] Côté M, Malo M C, Simard P, Messier M 2008 La gestion stratégique: Une approche fondamentale Montreal, QC: La Chenelière, $368 \mathrm{p}$

[25] Harrison J, Enz C 2005 Hospitality Strategic Management Hoboken, NJ: John Wiley \& Sons 676 p 